\title{
Hubungan Regulasi Diri dengan Prokrastinasi Akademik
}

\author{
Sedyawati* \\ Sekolah Menengah Pertama Negeri 6 Malang, Jl. Kawi No. 15A Malang, Jawa Timur, Indonesia \\ *Penulis korespondensi, Surel: dyahsedyawati83@gmail.com
}

Paper received: 28-9-2021; revised: 12-10-2021; accepted: 19-10-2021

\begin{abstract}
Academic procrastination is a behavioral tendency to procrastinate tasks that occur in students. Factors that influence it include the lack of strategies in self-regulation or self-regulation (selfregulated learning). As one of the countries affected by the COVID-19 pandemic, Indonesia is implementing learning from home. In this condition, students are expected to have skills in managing themselves in learning during the learning process from home. This quantitative study examines the relationship between self-regulated learning and students' academic procrastination during the pandemic. The population of this research is the students of SMP Negeri 6 Malang, and the research sample uses random cluster sampling so that the number of students obtained is 168 consisting of class VII, class VIII, and class IX. The data collection uses a self-regulated learning scale and an academic procrastination scale on google forms distributed through online class Whatsapp groups. The data analysis technique used is a bivariate correlation to determine the relationship between the two variables. The data analysis results showed no significant relationship between self-regulated learning and students' academic procrastination.
\end{abstract}

Keywords: self regulated learning; academic procrastination; pandemic period

\begin{abstract}
Abstrak
Prokrastinasi akademik merupakan kecenderungan perilaku menunda-nunda tugas yang terjadi pada siswa. Faktor yang mempengaruhi prokrastinasi akademik, antara lain kurangnya strategi pengaturan diri atau regulasi diri. Regulasi diri dibutuhkan siswa, terutama dalam kondisi kurang menguntungkan pada saat ini yaitu pandemi covid-19. Situasi saat ini menuntut siswa memiliki keterampilan mengatur diri yang baik agar terhindar dari kebiasaan menunda-nunda tugas. Tujuan penelitian ini untuk mengetahui hubungan antara regulasi diri dan prokrastinasi akademik selama pandemi covid-19. Populasi penelitian adalah siswa SMP Negeri 6 Malang, teknik pengambilan sampel menggunakan cluster random sampling dan diperoleh 167 siswa kelas VII, kelas VIII dan kelas IX. Pengumpulan data menggunakan skala regulasi diri dan skala prokrastinasi akademik. Teknik analisis data penelitian yaitu korelasi bivariat. Hasil analisis data menunjukkan bahwa tidak ada hubungan yang signifikan antara regulasi diri dengan prokrastinasi akademik siswa selama pandemi covid-19.
\end{abstract}

Kata kunci: regulasi diri; prokrastinasi akademik; masa pandemi

\section{Pendahuluan}

World Health Organization atau yang dikenal dengan WHO pada bulan Maret 2020 mengumumkan bahwa covid-19 yang sedang terjadi di seluruh dunia disebut sebagai pandemi global (Kompas, 2020) dan Indonesia menjadi salah satu negara yang merasakan dampak pandemi covid-19. Kehadiran pandemi covid-19 menjadi suatu tantangan yang tidak dibayangkan sebelumnya karena semua aspek kehidupan merasakan dampak pandemi, tidak terkecuali sektor pendidikan. Kondisi ini mendorong pemerintah untuk membuat kebijakan dalam rangka memutus penyebaran covid-19, salah satunya penutupan sekolah.

Penutupan sekolah mulai diberlakukan sejak 21 April 2020 dan sebanyak 191 negara mematuhi keputusan yang telah ditetapkan oleh UNESCO tersebut. Akibatnya sebanyak 1,5 
milyar pelajar dan 63 juta guru merasakan dampak dari kebijakan tersebut karena harus menerapkan belajar dari rumah. Kondisi tersebut berdampak munculnya masalah dan strategi baru dalam pembelajaran. Berdasarkan hasil survey UNICEF, 66 persen dari 60 juta peserta didik dari berbagai jenjang pendidikan menyatakan bahwa mereka tidak nyaman dengan pembelajaran online (Kasih, 2020).

Negara di Asia Tenggara tidak luput dari kasus covid-19, hampir semua negara di wilayah ini terdampak pandemi covid-19. Hal ini berdampak pada berbagai sektor kehidupan diantaranya adalah pendidikan. Menurut Pusat Studi Sosial Asia Tenggara UGM, 2020, Sebagai contoh Singapura sebagai negara paling maju di Asia Tenggara menerapkan belajar dari rumah dengan berbagai kendala yang dihadapi.

Tidak jauh berbeda dengan Indonesia, sebagai salah satu negara terdampak covid-19, maka sektor pendidikan di Indonesia menerapkan pembelajaran dari rumah selama pandemi berlangsung sejak Maret 2020 hingga saat ini. Ketidakmampuan siswa dalam mengelola diri dalam pembelajaran daring mengakibatkan terbengkalainya tugas-tugas sekolah yang harus dikerjakan.

Berdasarkan asesmen non kognitif yang dilancarkan guru BK di SMP Negeri 6 Malang, banyak siswa yang mengalami ketidaknyamanan dalam belajar daring. Diantaranya rasa bosan belajar daring, tidak memahami materi serta tidak dapat mengatur waktu belajar. Ketidaknyamanan ini akhirnya menimbulkan rasa malas untuk belajar dan mengerjakan tugas. Lebih memilih bermain dengan gawainya yang sejatinya diperuntukkan sebagai media untuk belajar dan mengerjakan tugas. Berdasarkan studi dokumentasi yang peneliti lakukan dalam google classroom, lebih dari $50 \%$ siswa menunda bahkan tidak mengumpulkan tugasnya hampir di semua mata pelajaran. Hal tersebut dikuatkan juga melalui wawancara yang dilakukan peneliti pada wali kelas bahwa lebih dari 50\% siswa sering terlambat mengumpulkan tugas daringnya.

Perilaku prokrastinasi akademik ini semakin meningkat selama pembelajaran online. Prokrastinasi akademik adalah hal yang harus diwaspadai oleh siswa karena berpengaruh pada prestasi belajarnya. Apalagi di Kelas IX, nilai rapor digunakan sebagai dasar kelulusan dan kelanjutan studinya. Kogoya (2020) menyatakan prokrastinasi akademik berdampak negatif pada siswa karena peningkatkan stres akademik sebagai akibat tugas yang menumpuk dan waktu pengumpulan yang terkadang dapat bersamaan, tidak terselesaikannya tugas, dan tugas yang diselesaikan kurang maksimal. Selain berdampak pada akademis, berdampak pula pada pembentukan karakter siswa yaitu tanggung jawab dan mandiri dalam mengerjakan tugas akademiknya.

Santika (2016) menunjukkan bahwa individu dengan regulasi tinggi yang tinggi memiliki kecenderungan untuk melakukan prokrastinasi akademik yang rendah. Artinya siswa dengan regulasi diri yang baik, cenderung tidak menunda-nunda menyelesaikan tugas akademik. Hal ini disebabkan siswa mampu mengatur dan mengontrol diri sendiri secara mandiri dan dapat mengarahkan motivasi, pikiran, dan perilaku untuk mencapai tujuan akademik. Rizkyani dkk. (2020) menyatakan bahwa regulasi diri berhubungan dengan menunda-nunda pekerjaan. Hasil ini menunjukkan bahwa siswa dengan regulasi diri yang baik mampu mengarahkan diri sendiri agar lebih bertanggungjawab terhadap tugas akademik yang diperoleh dan diselesaikan secara tepat waktu. Wolters (2003) menyatakan aspek-aspek 
regulasi diri, antara lain strategi meregulasi kognisi, strategi meregulasi motivasi, strategi meregulasi perilaku, dan upaya untuk regulasi.

Steel (2007) menyatakan prokrastinasi berasal dari bahasa latin procrastination yang berarti menunda-nunda atau menangguhkan sampai hari berikutnya. Ferrari, Johnson, Mccown (dalam Ghufron, 2003) menyatakan ciri-ciri perilaku menunda-nunda tugas akademik, terdiri atas: (1)Terlambat menyelesaikan tugas, (2) Ketidaksesuaian antara waktu perencanaan menyelesaikan tugas dan kinerja nyata yang dihasilkan, (3) Memilih untuk melakukan kegiatan lain yang dirasa lebih menyenangkan dibandingkan menyelesaikan tugas akademik, (4) Menunda untuk memulai dan menyelesaikan tugas akademik yang diberikan.

Ferrari (dalam Ghufron \& Risnawati, 2010) membagu perilaku menunda-nunda ke dalam dua bentuk, yaitu functional procrastination dan dysfunctional procrastination. Lebih lanjut, dysfunctional procrastination masih dibagi lagi menjadi decisional procrastination dan avoidance procrastination. Bentuk perilaku menunda-nunda yang dikaji dalam penelitian ini mengarah pada disfunctional procrastination. Berdasarkan pendapat ahli tersebut, prokrastinasi akademik berarti kecenderungan untuk menunda-nunda aktivitas yang berhubungan dengan kegiatan belajar, misalnya menunda mengerjakan tugas, kuis ataupun ulangan harian yang diberikan guru.

\section{Metode}

Metode penelitian yang digunakan yaitu korelasi untuk mengetahui hubungan antara regulasi diri dan prokrastinasi akademik. Delgado-Gonzalez \& Herrera-Rivas (2021), Zaiyar (2020), Seyda \& Tabancali (2020) menyatakan bahwa metode korelasi merupakan salah satu jenis penelitian non-eksperimen untuk mengetahui hubungan antar variabel. Populasi penelitian ini adalah siswa SMP Negeri 6 Kota Malang. Sampel penelitian 167 siswa kelas VII, VIII, dan IX. Teknik pengambilan sampel penelitian korelasi ini menggunakan cluster random sampling.

Teknik pengumpulan data menggunakan skala regulasi diri dan skala prokrastinasi akademik yang dikembangkan sendiri mengacu pada teori dan hasil penelitian sebelumnya dalam menentukan indikator instrumen. Selanjutnya, validitas dan reliabilitas skala menggunakan Alpha Cronbach dengan nilai reliabilitas 0,895 untuk skala regulasi diri dan 0, 922 untuk skala prokrastinasi akademik. Item yang valid pada skala regulasi diri sebanyak 17 item dan skala prokrastinasi akademik sebanyak 16 item pernyataan. Teknik analisis data menggunakan korelasi bivariat untuk mengetahui hubungan antara regulasi diri dan prokrastinasi akademik.

\section{Hasil dan Pembahasan}

\subsection{Hasil}

Hasil penelitian menunjukkan bahwa regulasi diri tidak berhubungan dengan prokrastinasi akademik, hal ini ditunjukkan dengan nilai signifikansi $0,237>0,05$ dengan nilai r tabel 0,092<0,127. 
Jurnal Pembelajaran, Bimbingan, dan Pengelolaan Pendidikan, 1(10), 2021, 861-866

Tabel 1. Hasil Analisis Korelasi Regulasi Diri dan Prokrastinasi Akademik

\begin{tabular}{llcc}
\hline \multicolumn{4}{c}{ Correlations } \\
\hline & \multicolumn{1}{c}{ SRL } & PA \\
\hline Regulasi Diri & Pearson Correlation & 1 & 0,092 \\
& Sig. (2-tailed) & & 0,237 \\
& N & 167 & 167 \\
Prestasi Akademik & Pearson Correlation & 0,092 & 1 \\
& Sig. (2-tailed) & 0,237 & 167 \\
& $\mathrm{~N}$ & 167 & \\
\hline
\end{tabular}

Hasil analisis yang ditunjukkan pada tabel 1 menunjukkan bahwa regulasi diri siswa tidak memiliki hubungan dengan prokrastinasi akademik. Meskipun, adanya tidak hubungan tersebut menunjukkan hasil yang positif, artinya setiap peningkatan regulasi diri berdampak pada peningkatan prokrastinasi akademik. Namun, diduga ada variabel lain yang berpengaruh terhadap penelitian ini, sehingga menyebabkan tidak ditemukan hubungan antara regulasi diri dengan prokrastinasi akademik.

\subsection{Pembahasan}

Tujuan dari penelitian ini adalah untuk mengetahui hubungan antara regulasi diri dengan prokrastinasi akademik. Diharapkan individu dengan regulasi diri yang baik dapat kurang memiliki kebiasaan menunda-nunda menyelesaikan tugas, begitu pula sebaliknya. Hasil penelitian ini menunjukkan tidak adanya hubungan antara regulasi diri dengan prokrastinasi akademik. Tidak signifikannya hubungan antar keduanya dapat dijelaskan secara teoritis maupun metodologis. Secara teoritis tidak adanya hubungan antara regulasi diri dengan prokrastinasi akademik disebabkan karena adanya perbedaan individual dan hal-hal lain yang melatarbelakangi prokrastinasi akademik. Hal ini berarti kebiasaan individu untuk menunda-nunda menyelesaikan tugas akademik tidak hanya dipengaruhi oleh kemampuan regulasi diri saja, melainkan ada faktor lain yang mempengaruhinya. Sedangkan melalui tinjauan metodologis berkaitan dengan subyek penelitian yang memiliki karakteristik berbeda serta indikator dalam variabel yang diteliti.

Secara teoritis, adanya perbedaan individual pada diri siswa mempengaruhi cara siswa tersebut meregulasi dirinya dalam belajar. Morton, Thorkildsen \& Nicholls (dalam Ajisuksmo 1996) menyatakan bahwa kemampuan regulasi diri siswa dipengaruhi oleh cara pandang siswa terhadap mata pelajaran yang dihadapi. Artinya setiap siswa memiliki cara pandang yang berbeda-beda terhadap mata pelajaran yang sedang dihadapi. Cara pandang atau konsepsi ini diwujudkan dalam bentuk yang berbeda-beda, antara lain minat dan kesukaan. Siswa atau individu yang memiliki minat atau kesukaan yang tinggi terhadap suatu mata pelajaran akan berupaya untuk belajar secara maksimal dan memenuhi tugas-tugas yang diberikan.

Aspek lain yang diduga berpengaruh dalam kemampuan individu untuk regulasi diri yaitu cara orang tua siswa untuk membantu mengarahkan anak dalam rangka memecahkan masalah dan hal ini berpengaruh terhadap kemampuan anak untuk regulasi diri (Kontos, dalam Ajisukmo, 1996). Cara orangtua dalam mengasuh anak dan memberikan contoh dalam kehidupan sehari-hari anak untuk membangun regulasi diri yang baik, berpengaruh terhadap kemampuan regulasi diri anak. Bentuk contoh perilaku atau cara asuh orang tua agar dapat 
membantu anak mengembangkan regulasi diri, antara lain mengatur waktu dengan baik dalam kehidupan sehari-hari untuk membedakan kegiatan yang penting dan tidak penting dilakukan.

Hal lain yang mempengaruhi prokrastinasi akademik siswa di masa pandemi berbeda dengan yang dialami siswa sebelum pandemi. Pada masa pandemi siswa mengalami beberapa hal diantaranya adalah kejenuhan belajar daring. Menurut Rozzaqyah, 2021, hal yang mempengaruhi prokrastinasi akademik siswa, khususnya di masa pandemi adalah kejenuhan belajar, yaitu semakin tinggi kejenuhan belajar maka akan semakin tinggi pula tingkat prokrastinasi akademik. Kejenuhan belajar dan prokrastinasi akademik adalah dua gejala perilaku yang dapat mempengaruhi kinerja, semangat, dan hasil belajar peserta didik. Oleh karena itu, keduanya penting untuk dipahami agar dapat diminimalisir dan diselesaikan agar tidak memberikan dampak yang lebih besar pada prokrastinasi akademik siswa.

Sedangkan secara metodologis, tidak adanya hubungan antara regulasi diri dengan prokrastinasi akademik dapat disebabkan karena belum dianalisis kaitannya pola asuh orang tua dan persepsi individu, sehingga data yang dihasilkan kurang mencukupi. Hal lain adalah subyek penelitian yang bervariasi kelasnya dan jumlahnya yang kurang dari yang diharapkan (167 siswa dari 750 siswa).

\section{Simpulan}

Hasil penelitian menunjukkan bahwa tidak ada hubungan yang signifikan antara regulasi diri dengan prokrastinasi akademik siswa di masa pandemi. Tidak signifikannya hubungan antara keduanya disebabkan karena adanya perbedaan individual dan faktor lain yang melatar belakangi penyebab terjadinya prokrastinasi akademik pada diri siswa. Peneliti selanjutnya, diharapkan dapat mengembangkan intervensi yang tepat untuk diberikan pada siswa yang mengalami prokrastinasi akademik. Selain itu, peneliti selanjutnya perlu memperhatikan variabel pola asuh orang tua dan persepsi siswa yang diduga memberikan pengaruh terhadap pembentuk prokrastinasi akademik.

\section{Daftar Rujukan}

Delgado-Gonzalez, A., \& Herrera-Rivas, L. (2021). Motivation and English Achievement in Mexican Teacher Students: A Correlation Study. International Education Studies, 14(3), 96-104.

Ghufron, M. N., \& S., R. R. (2016). Teori-Teori Psikologi.Yogyakarta: Ar Ruzz Madia

Rizkyani, A., Feronika, T., \& Saridewi, N. (2020). Hubungan antara self regulated learning dengan prokrastinasi akademik pada mahasiswa pendidikan kimia di masa pandemi Covid-19. EDUSAINS, 12(2), 252-258.

Rozzaqyah, F. (2021). Hubungan kejenuhan belajar dalam jaringan dengan prokrastinasi akademik. Jurnal Konseling Komprehensif: Kajian Teori dan Praktik Bimbingan dan Konseling, 8(1), 8-17.

Santika, W. S., \& Sawitri, D. R. (2017). Self-regulated learning dan prokrastinasi akademik pada siswa kelas XI SMA Negeri 2 Purwokerto. Jurnal Empati, 5(1), 44-49.

Santrock, J. W., \& Santrock, J. W. (2007). Psikologi Pendidikan. Jakarta: Kencana Prenada Media Group.

Seyda, B. A. S., \& Tabancali, E. (2020). Correlations between teachers' personality, psychological safety perception and teacher voice. Eurasian Journal of Educational Research, 20(85), 185-204.

Steel, P. (2010). Arousal, avoidant and decisional procrastinators: Do they exist?. Personality and Individual Differences, 48(8), 926-934.

Triyono. (2014). Hubungan Antara Efikasi Diri Dan Regulasi Emosi Dengan Prokrastinasi Akademik Siswa SMA. Laporan Penelitian (tidak dipublikasikan).

Wolters, C. A., Pintrich, P. R., \& Karabenick, S. A. (2005). Assessing academic self-regulated learning. In What do children need to flourish? (pp. 251-270). Springer, Boston, MA. 
Jurnal Pembelajaran, Bimbingan, dan Pengelolaan Pendidikan, 1(10), 2021, 861-866

Zaiyar, M., Rusmar, I., \& Yuniarti, T. (2020). Correlation between Students' Mathematical and Logical Spatial Intelligence in Terms of Understanding Concepts. Malikussaleh Journal of Mathematics Learning, 3(2), 76-79. 